\title{
ASOLECTIN SEPARATION OF PROTHROMBIN FROM PROCONVERTIN
}

\author{
By ARTHUR J. SEAMAN ${ }^{1}$ AND PAUL A. OWREN
}

(From the Department of Medicine, Oslo University Hospital, Rikshospitalet, Oslo, Norway)

(Submitted for publication October 6, 1955; accepted December 12, 1955)

All reported adsorbents of prothrombin simultaneously adsorb proconvertin, and practically all described techniques of elution have resulted in their simultaneous release from these adsorbents.

In this paper we present information about a material selectively removing prothrombin from an eluate containing prothrombin, proconvertin, and hemophilia B factor (PTC, Christmas factor). The substance exhibiting this unique behavior is asolectin.

In another communication (1) we have reported that suitable concentrations of asolectin used with the described technique selectively adsorb proaccelerin from citrated human plasma. Greater concentrations of asolectin, however, led to the loss of prothrombin and still greater concentrations to marked loss of fibrinogen reactivity. In both the latter instances, surprisingly, proconvertin activity was little reduced.

Accordingly, using the dialyzed eluate of washed barium sulfate that had adsorbed prothrombin, proconvertin, and hemophilia B factor from fresh oxalated normal human plasma, it was possible to demonstrate that selective, almost complete, removal of prothrombin activity by asolectin can be effected with only minor depletion of proconvertin activity. The ability of the asolectin treated eluate to shorten the partial thromboplastin time of hemophilia $\mathrm{B}$ plasma was moderately reduced.

\section{MATERIALS}

Oxalated normal platelet poor plasma was prepared as previously described (1). The plasma was harvested with a Pasteur pipette and used immediately for barium sulfate adsorption.

Barium sulfate (Baker) analytical grade.

0.9 per cent sodium chloride solution.

$0.006 M$ sodium citrate solution.

$0.14 M$ sodium citrate solution.

Asolectin (Associated Concentrates, Inc., 57-01 32nd

1 Fulbright Research Scholar in Norway, 1954-1955. Present address : Division of Experimental Medicine, University of Oregon Medical School, Portland, Oregon.
Avenue, Woodside, New York) Lot Number 2085.

Parafilm.

Cellophane dialyzing membrane.

Russell viper venom (Stypven, Burroughs Wellcome and Company, London, England) diluted 1:40,000 in a $1: 30$ suspension of cephalin in veronal buffer was prepared by the technique of Hjort, Rapaport, and Owren (2) as was:

Prothrombin free ox plasma.

Citrated, proconvertin-deficient plasma was prepared from the blood of a patient congenitally deficient in this factor as previously described (3).

Citrated, hemophilia $B$ plasma was similarly prepared from the blood of a patient with the classical laboratory and clinical findings of hemophilia B (PTC deficiency, Christmas disease). The supernatant plasma was transferred with a Pasteur pipette to a glass bottle, and glassactivated (4). It was then decanted and bottled in aliquots which were stored at minus $20^{\circ} \mathrm{C}$. and thawed immediately before use.

Saline extract human brain thromboplastin was prepared as previously described (5).

Aged citrated human serum was prepared as described by Owren and Aas (6) and by Aas (7).

Calcium chloride aqueous solutions were prepared in the molarities indicated in the individual test systems.

Diluting fluid $I$ and $I I$ were prepared as previously described (1).

Veronal buffer (pH 7.35, ionic strength 0.154 ) was prepared as described previously (2).

Buffer saline was prepared as previously described (1). Adsorbed ox plasma was prepared as previously described (6) by passing fresh oxalated ox plasma once through a 20 per cent asbestos, then twice through a 50 per cent asbestos filter.

Accelerin-calcium chloride $30 \mathrm{mM}$ was prepared by adding $0.5 \mathrm{ml}$. of thrombin (Hemoclaudan Adrenon Leo, Lövens Kemiske Fabrik, Köbenhavn, 100 units per ml. dissolved in veronal buffer) to $10 \mathrm{ml}$. of adsorbed ox plasma at $37^{\circ} \mathrm{C}$. After 30 minutes' incubation, the fibrin was removed from the clotted plasma. Thrombin addition, incubation, and defibrination were repeated two more times. The resulting accelerin was then diluted with an equal volume of $60 \mathrm{mM}$ calcium chloride solution to produce accelerin-calcium chloride $30 \mathrm{mM}$. Aliquots were stored at minus $20^{\circ} \mathrm{C}$. and retained sufficient potency for use for periods of one week or more. During tests the accelerin-calcium chloride $30 \mathrm{mM}$ was kept at $37^{\circ} \mathrm{C}$. 


\section{METHOD}

Using a minor modification of the technique described by Surgenor, Alexander, Goldstein, and Schmid (8), $100 \mathrm{ml}$. of fresh oxalated normal plasma was mixed with $100 \mathrm{mg}$. of barium sulfate per $\mathrm{ml}$. and mixed with a glass stirring rod for 30 minutes at $4^{\circ} \mathrm{C}$. It was then centrifuged at $2500 \mathrm{rpm}\left(2^{\circ} \mathrm{C}\right.$.) for 30 minutes. The barium sulfate sediment was drained and washed by mixing with $30 \mathrm{ml}$. physiological saline with a glass rod, then recentrifuged at $2500 \mathrm{rpm}\left(2^{\circ} \mathrm{C}\right.$.) for 30 minutes. The saline supernate was decanted and discarded. The saline wash, centrifugation, and decanting were repeated. The barium sulfate was then stirred with $30 \mathrm{ml}$. of $0.006 \mathrm{M}$ sodium citrate solution for 5 minutes and again centrifuged at $2500 \mathrm{rpm}\left(2^{\circ} \mathrm{C}\right.$.) for 30 minutes. The wash fluid was decanted and the barium sulfate was stirred with $30 \mathrm{ml}$. of $0.14 \mathrm{M}$ sodium citrate solution and allowed to elute for 30 minutes at $4^{\circ} \mathrm{C}$. The inactive precipitate was sedimented by centrifugation at 2500 rpm $\left(2^{\circ} \mathrm{C}\right.$.) for 30 minutes. The supernate was transferred to a cellophane membrane and dialyzed overnight against two 1-L. changes of physiological saline solution at $4^{\circ} \mathrm{C}$. After saving a sample of the dialyzed eluate for initial assays, the remainder was transferred in aliquots to a mortar and $30 \mathrm{mg}$. of asolectin per $\mathrm{ml}$. of eluate was ground with a pestle until it was evenly suspended. The suspension was placed in a glass tube and incubated at $4^{\circ} \mathrm{C}$. for 60 minutes, then transferred to lusteroid tubes, capped, and spun at $40,000 \mathrm{rpm}\left(2^{\circ} \mathrm{C}\right.$.) for 60 minutes. The tubes were removed from the rotor with utmost care to avoid agitating the contents. The central screw plug in the cap was removed, and a lumbar puncture needle attached to a 20-ml. Lur-lock syringe was carefully introduced to a point slightly above the tube bottom on the side opposite the sedimented asolectin. By gentle aspiration, the clear supernate was collected from each tube and pooled. A sample of this once-asolectin-treated eluate was saved for assay, and the balance was added in aliquots to a mortar containing $30 \mathrm{mg}$. of asolectin per $\mathrm{ml}$. of once-asolectin-treated eluate. With a pestle, this was ground to an even suspension. The suspension was transferred to a glass tube and kept at $4^{\circ} \mathrm{C}$. for 1 hour. It was then transferred to lusteroid tubes, capped, and spun at $40,000 \mathrm{rpm}\left(2^{\circ} \mathrm{C}\right.$.) for 1 hour. Aspiration of the clear supernates was carried out and these pooled and labelled "twice-asolectintreated eluate." All specimens were then subjected to assay.

All incubations and tests were performed in duplicate at $37^{\circ} \mathrm{C}$.

The prothrombin assay systems of Hjort, Rapaport, and Owren (2) and of Owren and Aas (6) were both used.

The proconvertin assay system using plasma from a patient congenitally deficient in proconvertin as substrate was as previously described $(1,3)$.

Hemophilia B plasma partial thromboplastin time corrections :

Asolectin suspension (1:120 in buffer saline)

Citrated, glass-activated,

Hemophilia B plasma, undiluted $\quad 0.2 \mathrm{ml}$.

Test material, undiluted $0.2 \mathrm{ml}$.

Incubate 3 minutes. Time from addition of :

Accelerin-calcium chloride $30 \mathrm{mM}$. $\quad 0.2 \mathrm{ml}$.

\section{COMMENT}

Prothrombin concentration is markedly reduced by treating an eluate rich in prothrombin and proconvertin with $30 \mathrm{mg}$. of asolectin per $\mathrm{ml}$. Proconvertin activity is little reduced. A second treatment with $30 \mathrm{mg}$. of asolectin per $\mathrm{ml}$. of the once-

TABLE I

Results*

\begin{tabular}{|c|c|c|c|c|c|c|}
\hline \multirow{2}{*}{$\begin{array}{l}\text { Material tested } \\
\text { Initial eluate } \\
\text { Once-asolectin-treated eluate } \\
\text { Twice-asolectin-treated eluate }\end{array}$} & \multicolumn{3}{|c|}{$\begin{array}{l}\text { Proconvertin assay } \\
\text { Duplicate determinations }\end{array}$} & \multicolumn{3}{|c|}{$\begin{array}{c}\text { Prothrombin assay } \\
\text { [Hjort, Rapaport, and Owren (2)] } \\
\text { Duplicate determinations }\end{array}$} \\
\hline & \begin{tabular}{c|} 
sec. \\
14.4 \\
15.7 \\
23.2
\end{tabular} & $\begin{array}{c}\text { sec. } \\
14.8 \\
15.9 \\
23.2\end{array}$ & $\begin{array}{r}\% \\
>100 \\
>100 \\
70\end{array}$ & $\begin{array}{r}\text { sec. } \\
24.6 \\
76.4 \\
202.4\end{array}$ & $\begin{array}{r}\text { sec. } \\
24.6 \\
77.2 \\
204.0\end{array}$ & $\begin{array}{c}\% \\
100 \\
19 \\
0.5\end{array}$ \\
\hline
\end{tabular}

* Twice-asolectin-treated eluate (diluted $1: 10$ in diluting fluid II) when tested in the aged citrated human serum method for prothrombin assay (6) gave the following times: 83.7, 83.0 ( $<1$ per cent) as contrasted with $98.2,93.5$ for buffer ( 0 per cent) control.

In the hemophilia B partial thromboplastin time correction using $0.2 \mathrm{ml}$. hemophilia B plasma as substrate, $0.2 \mathrm{ml}$. of the following undiluted materials added as test substances gave the recorded results from the time accelerin- $\mathrm{CaCl}_{2}$ $30 \mathrm{mM}$ was added:

0.2 Hemophilia B plasma

0.2 Initial eluate

0.2 Once-asolectin-treated eluate

0.2 Twice-asolectin-treated eluate

0.2 Normal plasma

\begin{tabular}{cr}
\multicolumn{2}{c}{$\begin{array}{c}\text { Duplicate determinations } \\
\text { sec. }\end{array}$} \\
264.7 & sec. \\
25.4 & 266.2 \\
45.9 & 27.4 \\
56.3 & 44.6 \\
45.2 & 56.1 \\
& 46.7
\end{tabular}


treated eluate leaves only traces of prothrombin behind, while proconvertin activity is reduced to only 70 per cent of normal plasma's content. Hemophilia $B$ factor activity seems to be reduced only moderately. It would appear that the sodium citrate eluate of barium sulfate adsorbent of fresh oxalated hemophilia B plasma or asolectin treated hemophilia $B$ serum should necessarily be used if one wishes to prepare proconvertin free of prothrombin and hemophilia B factor.

Attempts to elute prothrombin from the asolectin with $0.14 \mathrm{M}$ sodium citrate, with 0.9 per cent sodium chloride, with distilled water, with 1 per cent acetic acid, and with phosphate buffer ( $\mathrm{pH} \mathrm{8.0)} \mathrm{have} \mathrm{not} \mathrm{succeeded.} \mathrm{Attempted} \mathrm{solu-}$ tion of asolectin and precipitation of prothrombin by adding a 10 per cent volume of ethyl ether $\left(4^{\circ} \mathrm{C}.\right)$, attempts to achieve differential solubility of prothrombin and asolectin in tri-fluoro acetic acid, and attempts to oxalate and competitively adsorb prothrombin on barium sulfate from the asolectin and elute it from the barium sulfate have all been unsuccessful. Efforts to separate the prothrombin are continuing. The probability that the bond between asolectin and prothrombin may be chemical rather than physical is recognized.

\section{SUM MARY}

Asolectin $30 \mathrm{mg}$. per ml. ground to an even suspension in a mortar and pestle with a dialyzed sodium citrate eluate of the barium sulfate adsorbent of fresh oxalated normal human plasma is capable of selectively and almost completely removing prothrombin activity. Proconvertin ac- tivity and the ability of the treated eluate to shorten the partial thromboplastin time of hemophilia B plasma are reduced to a much lesser degree. The asolectin suspension is incubated with the eluate for 60 minutes at $4^{\circ} \mathrm{C}$., then sedimented by centrifugation at $40,000 \mathrm{rpm}$ for 60 minutes $\left(2^{\circ} \mathrm{C}\right.$.).

Attempts to elute the prothrombin from asolectin have been unsuccessful to date.

\section{REFERENCES}

1. Seaman, A. J., and Owren, P. A., An asolectin adsorbed substrate for proaccelerin assay. J. Clin. Invest., 1956, 35, 145.

2. Hjort, P., Rapaport, S. I., and Owren, P. A., A simple, specific one-stage prothrombin assay using Russell's viper venom in cephalin suspension. J. Lab. \& Clin. Med., 1955, 46, 89.

3. Owren, P. A., Prothrombin and accessory factors. Clinical significance. Am. J. Med., 1953, 14, 201.

4. Rapaport, S. I., Aas, K., and Owren, P. A., The effect of glass upon the activity of the various plasma clotting factors. J. Clin. Invest., 1955, 34, 9.

5. Owren, P. A., A quantitative one-stage method for the assay of prothrombin. Scandinav. J. Clin. \& Lab. Invest., 1949, 1, 81.

6. Owren, P. A., and Aas, K., The control of dicumarol therapy and the quantitative determination of prothrombin and proconvertin. Scandinav. J. Clin. \& Lab. Invest., 1951, 3, 201.

7. Aas, K., Prokonvertin og konvertin; unders $\phi$ kelser over blodets koagulasjon, med spesielt henblikk på prokonvertin og konvertin. Thesis, Oslo, Akademisk Trykningssentral, 1952.

8. Surgenor, D. M., Alexander, B., Goldstein, R., and Schmid, K., A system for the separation of the protein components of human plasma. II. The components of the clotting process. J. Phys. \& Colloid Chem., 1951, 55, 94. 